\title{
CHINESE OR MALAY-MEDIUM SCHOOLS? A STUDY OF FACTORS INFLUENCING CHINESE PARENTS' CHOICE OF PRIMARY SCHOOLS IN SARAWAK, MALAYSIA
}

\author{
Diana Phooi-Yan Lee ${ }^{1}$, Su-Hie Ting ${ }^{2 *}$ and May-Chiun Lo ${ }^{3}$ \\ ${ }^{1}$ Polytechnic Kuching, Sarawak, MALAYSIA \\ ${ }^{2}$ Faculty for Language and Communication Studies, Universiti Malaysia \\ Sarawak, MALAYSIA \\ ${ }^{3}$ Faculty of Economics and Business, Universiti Malaysia Sarawak, MALAYSIA \\ *Corresponding author: shting@unimas.my / suhieting@gmail.com \\ Published online: 15 April 2017 \\ To cite this article: Lee, D. P-Y, S-H Ting and M-C Lo. 2017. Chinese or Malay-medium schools? \\ A study of factors influencing Chinese parents' choice of primary schools in Sarawak, Malaysia. \\ Kajian Malaysia 35(1): 41-67. https://doi.org/10.21315/km2017.35.1.3 \\ To link to this article: https://doi.org/10.21315/km2017.35.1.3
}

\begin{abstract}
This study examined factors that influence Chinese parents' choice of medium in primary schools in Sarawak, Malaysia. A questionnaire that was based on the Theory of Planned Behaviour was administered to investigate the influence of attitudes towards school, social pressure (subjective norms) and perceived behavioural control on parents' intentions for school choice. The survey was conducted with 397 Chinese respondents who had children in one of 21 Chineseand Malay-medium schools in Kuching, Sarawak. The results showed that the strongest influence on primary school choice was perceived behavioural control, which is the extent to which parents felt capable of paying fees and enrolling their children in the school of their choice. Positive attitudes towards Chinese schools also predicted choice for Chinese-medium schools. Parents who wanted their children to learn Mandarin and Mathematics and to have a Chinese cultural appreciation chose Chinese-medium schools. However, subjective norms had little influence on school choice. Collectively, attitudes, subjective norms and perceived behavioural control accounted for $44.0 \%$ and $32.4 \%$ of the variance in Chinese parents' intentions to choose Chinese- and Malay-medium schools, respectively. The findings suggest that there may be other factors that influence school choice, which should be investigated using interviews.
\end{abstract}

Keywords: Chinese schools, medium of instruction, Theory of Planned Behaviour, school choice, Malaysia 


\section{INTRODUCTION}

To date, studies in multilingual settings have shown that language prestige and practical concerns affect school choice. For example, Babaci-Wilhite's (2010) study in Tanzania revealed that most parents preferred English-medium schools even though they did not understand English because Kiswahili was not viewed as an academic language and was the medium of instruction in government schools. The Tanzanian parents believed that an English education could improve their children's learning abilities and opportunities in life. In South Africa, Evans and Cleghorn's (2014) survey showed that more parents preferred schools that offered English and Afrikaans compared to English-medium schools. The latter was preferred by older parents who had better English proficiency and believed that English was linked to power and high standards. Evans and Cleghorn (2014) found that the medium of instruction was only one factor that affected school choice, and additional influences include reputation (e.g., firm discipline, highstandards and ample resources) and proximity of the schools. In Hong Kong, parents believed that an English-medium education provided their children with better access to higher education and well-paid jobs. These parents objected to the implementation of Chinese as the default medium in education in September 1998 after Hong Kong was given to China (Tsui et al., 1999). In Singapore, the medium of instruction is not important for school choice because both public and privately funded international schools use English. In public schools, parents have to choose an ethnic language (Chinese, Malay, Tamil) as a cultural language (Chua, 2004, 2009). Parents choose privately funded international schools because there are smaller class sizes, diversity in the curriculum and student composition and less reliance on a merit-based system (Vidovich and Yap, 2008).

In Malaysia, research has focused on changes in the medium of instruction (e.g., Gill, 2005; Ridge, 2003; Tan, 2005; Ting 2010), but there are few empirical studies on school choice. In this context, choosing a Chinese- or Malay-medium school is more than a choice of medium of instruction. For the ethnic Chinese in Southeast Asia, Chinese education is indispensable for sustaining Chinese culture (Tan, 1997) as well as transmitting traditional values, the spirit of nationalism and political awareness (Ku, 2003). Most Chinesemedium schools have a large Chinese student population. Currently, Chinese students are the minority in Malay-medium public schools (Tan, Ngah and Darit, 2013). In the area of school choice, it is more important to study choice for primary schools rather than secondary schools because parents are more diverse in their choices at the primary level. In the eastern Malaysian state of Sarawak, demographic information from two studies also showed that there was more diversity in school choice at the primary level. Of 568 indigenous students in the study, 92.6\% attended Malay-medium primary schools, while this percentage increased to $98.4 \%$ at the secondary level (Ting and Ling, 2012). For the Chinese, Ting (2012) found that $90.2 \%$ of 348 Chinese students attended 
Chinese-medium primary schools, while only $3.2 \%$ continued with Chinesemedium secondary education. A majority $(96.6 \%)$ continued their secondary education in Malay-medium secondary schools. Students from different primary schools converge in Malay-medium secondary schools, which results in a more ethnically diverse student population (Ministry of Education, 2012). Furthermore, primary education establishes the foundation for children's future education, and studying in a predominantly Chinese or Malay school environment may influence children's worldviews of social and ethnic relations. Therefore, it is important to examine parental choice in primary schools.

\section{STUDY PURPOSE}

This study examined factors that influence Chinese parents' choice of medium of instruction for their children's primary education in Sarawak, Malaysia. The specific constructs of interest were attitudes towards school, social pressure (subjective norms) and perceived behavioural control in choosing the school. The hypotheses for this study were:

H1: There is a difference in attitudes towards school between Chinese parents who chose Chinese- and Malay-medium primary schools.

$\mathrm{H} 2$ : There is a difference in the subjective norms that influence Chinese parents who chose Chinese- and Malay-medium primary schools.

H3: There is a difference in perceived behavioural control among Chinese parents who chose Chinese- and Malay-medium primary schools.

H4: There is a relationship among attitudes towards school, subjective norms, perceived behavioural control and intentions for school choice.

\section{BACKGROUND ON MALAYSIA}

The Chinese in Malaysia are a minority group who are at least second- or thirdgeneration descendants of immigrants from China, with a larger population than in neighbouring countries, such as Indonesia and Thailand. The Malaysian population of 30.9 million includes $50.3 \%$ Malay, $21.7 \%$ Chinese, $11.8 \%$ Sabah and Sarawak Indigenous people groups, $6.62 \%$ Indian and $0.87 \%$ from other backgrounds (Department of Statistics Malaysia, 2015). The Chinese comprise $22.63 \%$ of the total Sarawak state population of 2.7 million, and the largest Chinese dialect group is the Foochow, who primarily live in Sibu, Sarikei and 
Bintangor (Department of Statistics Malaysia, 2016). The present study was conducted in Kuching, the capital city of Sarawak, where Hokkien is the largest Chinese dialect group (37.7\%), followed by Hakka (20.4\%) (Department of Statistics Malaysia, 2015).

In Malaysia, Malay (the national and official language) is the medium of instruction in public schools, and English is taught as a second language. Vernacular languages are taught as subjects when requested by at least 15 parents (Smith, 2003). As such, Chinese, Tamil, Kadazandusun and Iban have been offered as subjects in public primary schools, which are referred to as Sekolah Kebangsaan, or national schools. These national schools are fully funded by the government. Sekolah Jenis Kebangsaan or national-type schools use Mandarin or Tamil as the medium of instruction. For non-language subjects, the national and national-type schools use the same syllabus that is determined by the Ministry of Education.

The national-type schools are partially funded by the government. Capital Aid Fund and Special Building, Upgrade and Maintenance Funds are provided for repairing amenities, purchasing text books, paying utility bills and teacher's and non-academic support staff's salaries, maintaining school cleanliness, constructing new blocks and building maintenance (The Borneo Post, 10 April 2013). When the operating costs exceed the government allocation, the schools must raise their own funds. The national-type schools are different from private schools that are not funded by the government. These private schools may use English or Chinese as the medium of instruction. For example, the independent Chinese secondary school uses its own curriculum and the Malaysian government does not recognise its academic qualifications (Santhiram and Tan, 2015). Enrolment in Chinese national-type primary schools has been decreasing since the year 2000 (The Star, 10 January 2015). The number of under-enrolled Chinese primary schools is highest in the state of Sarawak. As reported in the Chinese newspaper, Huajiao Daobao (2011), 119 of 221 Chinese primary schools in Sarawak were under-enrolled in 2010 (as cited in Santhiram and Tan, 2015: 6). Under-enrolment is defined as less than 150 students in the school, which decreases the sustainability of continuing to operate the school. Decreasing enrolment has been attributed to the declining birth rate in the Chinese community and rural-urban migration (Santhiram and Tan, 2015). The present study examined Chinese-medium primary schools that were national-type and not private Chinese schools.

Most of the Chinese in Malaysia choose Chinese-medium schools (Ting, 2013). For example, in Sarawak, school enrolment in Kuching in 2014 demonstrated that $88 \%$ of Chinese students were studying in Chinese-medium and $12 \%$ were in Malay-medium primary schools. Nationally, $86 \%$ of the enrolment in national (Malay-medium) primary schools are Malay students, $86 \%$ of the enrolment in Chinese-medium schools are Chinese students, and $96 \%$ of the enrolment in Tamil-medium schools are Indian students (Ministry of 
Education, 2012). In the context of nation building, Chinese-medium schools are believed to propagate divisiveness and ethnic dissent compared to Malaymedium schools, which are viewed as fostering national integration (Raman and Tan, 2010; Teh, 2014). However, Chinese educationists and a portion of the Chinese community are adamant about continuing Chinese-medium schools, as they are viewed as one of the three institutions that promote Chinese identity in Malaysia, with the other two being Chinese mass media and Chinese associations (Suryadinata, 1997).

\section{THEORETICAL FRAMEWORK FOR THE STUDY}

The theoretical framework for this study is the Theory of Planned Behaviour (TPB), (Ajzen, 1991; Ajzen and Fishbein, 1975), which was designed to study factors that influence decision making. TPB has been employed in many studies that examine decision-making processes, including moral behaviour (Man, 1998; Vallerand et al., 1992), information communication and technology engagement (Siragusa and Dixon, 2009), online shopping intentions (Chuchinprakarn, 2005), and choice of travel mode (Bamberg, Ajzen and Schmidt, 2003). TPB is also useful for predicting behaviours, such as smoking cessation (Norman, Conner and Bell, 1999) and career choice (Vincent, Peplau and Hill, 1998; Zellweger, Sieger and Halter, 2010). TPB has been well-tested in the educational domain and is used to study school choice (Goh, 2007), institutions of higher education (Chen and Zimitat, 2006), business ethics courses (Randall, 1994) and intentions for teaching online public relations courses (Knabe, 2012).

TPB examines how behavioural intentions and behaviours are determined by attitudes towards behaviours, subjective norms, and perceived behavioural control. Attitudes towards behaviour refer to the overall subjective evaluation of performing or not performing a behaviour. Subjective norms refer to social pressures from spouses, family, peers and other influential people for performing or not performing a behaviour. Perceived behavioural control is the extent to which an individual feels capable or incapable of performing a behaviour. These three motivations influence an individual's intention for performing a given behaviour. For behaviours under an individual's volitional control, there is high perceived behavioural control, which results in a strong intention for performing a behaviour. For behaviours that are not under complete volitional control, such as a college graduate applying for an advertised position, the intention to apply for the job may not predict the behaviour, which is obtaining the position (Ajzen, 2002). A limitation of TPB is that the actual behaviour may not be the same as the behavioural intention (Fleming et al., 2014; Goh, 2007), specifically for behaviours that are not totally under volitional control. However, this limitation can be mitigated by examining variables that influence behavioural intention immediately after the behaviour has been 
performed (Cheng and Chu, 2014; Randall, 1994; Pineda, 2009). To address this limitation, the present study investigated Chinese parents' school choice soon after making the choice, that is, when their children were in primary school.

TPB has been extensively used in studies on choice in educational institutions in monolingual settings where the choice does not include the medium of instruction. Results have shown that attitudes towards behaviour is the best predictor of school choice in Australia (Goh, 2007), overseas universities (Chen and Zimitat, 2006; Prugsamatz, 2009), business courses (Randall, 1994; Pineda, 2009) and Language Other Than English (LOTE) courses in Australia (Ham, 2008). Goh (2007) found that friends and relatives also influence school choice (see also Chen and Zimitat 2006; Ham 2008; Pineda 2009) but subjective norms did not significantly influence choice for a business ethics course (Randall, 1994). Perceived behavioural control does not contribute to predicting intention (Goh, 2007; Ham, 2008; Prugsamatz, 2009; Randall, 1994). Taken together, attitudes towards behaviour, subjective norms and perceived behavioural control predict $30 \%$ to $67 \%$ of the intention to make an educational choice. Importantly, the use of TPB allows researchers to study the relative importance of motivations that underlie the choice. This is an important step forward in the area of school choice because most research has used frequencies and percentages to determine the relative importance of reasons for school choice. Some of the reasons can be clearly grouped together but are presented as different (Bagley, 1996; Bussell, 1998; 2000; Denessen, Driessena and Sleegers, 2005; Goldring and Hausman, 1999; Jackson and Bisset, 2005; Kleitz et al., 2000). TPB provides a common framework for data collection and comparisons of findings. In addition to the advantage of studying the relative importance of factors that influence school choice, TPB also allows for findings to be compared across studies to achieve a better understanding of parental school choice.

\section{METHOD}

\section{Respondents}

The respondents comprise 397 Chinese parents who had children in primary school in Kuching, Sarawak in East Malaysia. The Chinese parents were selected based on their Chinese names from school records and their self-identification as Chinese. The parents were from 14 Malay $(n=198)$ and 7 Chinese-medium primary schools $(n=199)$. This study included more Malay-medium schools because there were less Chinese students in the schools. In fact, some of the schools (such as SK Combined and SK Tabuan Jaya) had no Chinese students, as most students were from mixed marriage families. The schools that were included in the study were in a 10-kilometre radius from Kuching city to focus 
the study on urban schools because factors that influence school choice may be different in rural areas.

The respondents were 35.2 years old $( \pm 7.61)$, primarily female $(64.2 \%)$, Chinese-educated $(59.6 \%)$ and about half had completed secondary education (46.9\%). See Table 1 for respondent's demographic characteristics. This paper uses the acronyms CP and MP to refer to parents who chose Chinese and Malaymedium primary schools, respectively.

Table 1: Sample demographic characteristics

\begin{tabular}{|c|c|c|c|c|c|c|c|}
\hline & \multirow[t]{2}{*}{ riable } & \multicolumn{2}{|c|}{$\begin{array}{l}\text { Parents with children } \\
\text { in Chinese-medium } \\
\text { primary school } \\
(\mathrm{n}=199)\end{array}$} & \multicolumn{2}{|c|}{$\begin{array}{l}\text { Parents with children } \\
\text { in Malay-medium } \\
\text { primary school } \\
(\mathrm{n}=198)\end{array}$} & \multicolumn{2}{|c|}{$\begin{array}{c}\text { Total } \\
(\mathrm{n}=397)\end{array}$} \\
\hline & & Frequency & $(\%)$ & Frequency & $(\%)$ & Frequency & $(\%)$ \\
\hline \multirow[t]{2}{*}{ Gender } & Female & 128 & 64.3 & 127 & 64.1 & 255 & 64.2 \\
\hline & Male & 71 & 35.7 & 71 & 35.9 & 142 & 35.8 \\
\hline \multirow[t]{5}{*}{ Age } & $20 \mathrm{~s}$ & 10 & 5.0 & 6 & 3.0 & 16 & 4.0 \\
\hline & $30 \mathrm{~s}$ & 123 & 61.8 & 79 & 39.9 & 202 & 50.8 \\
\hline & $40 \mathrm{~s}$ & 55 & 27.6 & 85 & 43.0 & 140 & 35.3 \\
\hline & $50 \mathrm{~s}$ & 10 & 5.0 & 24 & 12.1 & 34 & 8.6 \\
\hline & $60 \mathrm{~s}$ & 1 & 0.5 & 4 & 2.0 & 5 & 1.3 \\
\hline \multirow{3}{*}{$\begin{array}{l}\text { Medium } \\
\text { of } \\
\text { primary } \\
\text { education }\end{array}$} & Chinese & 170 & 85.4 & 67 & 33.8 & 237 & 59.6 \\
\hline & English & 8 & 4.0 & 72 & 36.4 & 80 & 20.2 \\
\hline & Malay & 21 & 10.6 & 59 & 29.8 & 80 & 20.2 \\
\hline \multirow{4}{*}{$\begin{array}{l}\text { Level } \\
\text { of } \\
\text { education }\end{array}$} & Primary & 15 & 7.5 & 18 & 9.1 & 33 & 8.3 \\
\hline & Secondary & 92 & 46.2 & 94 & 47.5 & 186 & 46.9 \\
\hline & College & 40 & 20.1 & 43 & 21.7 & 83 & 20.9 \\
\hline & University & 52 & 26.1 & 43 & 21.7 & 95 & 23.9 \\
\hline
\end{tabular}

${ }^{*}$ Some $\%$ do not equal 100 due to rounding

\section{Questionnaire}

The questionnaire was formulated in accord with TPB to investigate the relative influence of attitudes towards behaviour ( $\mathrm{AB})$, subjective norms (SN), and perceived behavioural control (PBC) on intentions (INT) to choose either Chinese or Malay as the medium of instruction for children's primary education. The items are shown in Table 2. First, Attitude (AB) items assessed beliefs about the perceived benefits of studying in Chinese- or Malay-medium schools on a 10 -point scale $(1=$ strongly disagree; $10=$ strongly agree). Second, eight items were adapted from Chen and Zimitat (2006) and Randall (1994) to assess 
subjective judgements of important others' views about school choice. Parents rated their agreement with each item on a 10-point scale ( 1 = extremely unlikely; $10=$ extremely likely) that assessed whether their parents, spouse, child, other family members, friends and other parents in the school influenced their choice of medium of instruction. Third, PBC was assessed with five, 10-point scaled items that were adapted from Randall (1994) and Armitage, Conner and Norman (1999) to evaluate perceived confidence and ease in enrolling their child in the school of their choice. The dependent variable, intention (INT) to choose a Chinese- or Malay-medium school was measured with two items that were adapted from Randall (1994), with a scale that ranged from 1 (extremely weak) to 10 (extremely strong). Because the questionnaire that was used in the present study was based on validated measures from other studies, the questionnaire was valid.

The questionnaire was pilot tested with 30 respondents. The only change that occurred after the pilot study was for one item that assessed attitudes towards behaviour. Initially, the question used a ranked order (i.e., 1 for "most likely to do", 2 for "likely to do" and 3 for "least likely to do"), but participants did not understand the question. Therefore, the item was changed to a 10-point Likert scale for the actual study, which was similar to the items in the remainder of the questionnaire.

The questionnaire was reliable, as the Cronbach Alpha values for both sets of questionnaires that were employed in the study were high: $\mathrm{AB}$ (CP: 0.939, MP: 0.938), SN (CP: 0.913, MP: 0.842), PBC (CP: 0.745, MP: 0.812) and INT (CP: 0.867 , MP: 0.867 ). The generally accepted criteria for reliability is 0.70 (Yi and Davis, 2003). The questionnaires were prepared in Chinese and Malay, and the accuracy of the translation was checked using the back translation method. The questionnaires that were distributed to parents with children in the Chineseand Malay-medium schools were the same except for the words "Chinese school" and "Malay school", which were interchanged in items that required a comparison between the two types of schools. For example, CP completed the item "I believe that Chinese school students are better than Malay school students in Bahasa Malaysia," while MP completed the item "I believe that Malay school students are better than Chinese school students in Bahasa Malaysia."

\section{Data Collection and Analysis Procedures}

The objectives of the study were addressed using a cross-sectional survey design. After obtaining permission for the study from the Malaysian Federal and State Education Departments, the first author approached principals from the selected schools to obtain their consent for the study. Several principals instructed their teachers to distribute the questionnaires. Other principals requested that the first author meet the parents during lunch and after school. Parents who agreed to participate in the study signed a consent form prior to completing the 
questionnaire. For ease of comparison, questionnaires continued to be distributed until 200 questionnaires were collected from each of the two groups of parents. Of the 726 questionnaires that were distributed, 400 were usable $(55.1 \%$ response rate). After checking the data for outliers, three respondents were eliminated from the data set, with 397 participants included in the data analysis.

Appendix 1 shows that the Kaiser-Meyer-Olkin Measure of Sampling Adequacy for both sets of data were greater than $0.50(0.817$ and 0.854 for parents with children in Chinese- and Malay-medium schools, respectively), which indicates that the underlying factors explained a large proportion of variance in the variables. Bartlett's test of Sphericity yielded a significant value (less than 0.05) and demonstrated that the variables were related and appropriate for a factor analysis.

The composite reliability test was conducted and the reliability values for each construct are shown in Table 3. The composite reliability test results were examined for cross-loading. With 400 respondents, if the value is less than 0.3 , then there are high cross-loadings in the items and a need to delete unreliable items. For the data that were collected from the parents of Chinese-medium students, there were four items that had to be deleted: Items 7 and 8 on SN and Items 4 and 5 on PBC. For the data from parents who chose Malay-medium primary school, the only item that was deleted was Item 7 on SN. Because only Item 7 on SN was common across the two data sets, "Most people who are important to me think that I should/should not enrol my children in a Chinese/Malay primary school" was the only deleted item. The correlation and regression results that are reported later in this paper exclude this item in the analysis.

The Variance Inflation Factor (VIF) and tolerance statistics identified the severity of multicollinearity in the matrix of predictor variables. The results showed that the VIF values were below 10 and the tolerance statistics were all above 0.1 , which suggests that there is no multicollinearity and that the data were reliable for further analysis. Because the data were from the respondents' survey responses, an $R^{2}$ of more than $15 \%$ is considered adequate for explaining the relationship between the independent and dependent variables (Hair et al., 1992). $\mathrm{AB}, \mathrm{SN}$ and $\mathrm{PBC}$ were included in a standard regression analysis to predict behavioural intentions for Chinese or Malay school choice as the medium of instruction for their children. Gender and age were used as control variables on intention in the regression analysis. 


\section{RESULTS AND DISCUSSION}

\section{Attitudes towards Behaviour}

Table 2 shows that there were significant differences between CP and MP for several aspects of Chinese- or Malay-medium education. Most CP believed that Chinese-medium schools were better than Malay-medium schools $(7.1 \pm 1.8)$, specifically for the qualification values, job prospects, achievement in Chinese, science and mathematics, development of diligence and openness to other races, and an appreciation of Chinese culture. In contrast, most MP had a neutral attitude towards Malay-medium schools $(5.7 \pm 2.0$; the mid-point of the 10-point scale is 5.5). In fact, MP acknowledged that Chinese-medium students had several advantages. MP believed that Malay-medium students were not better than Chinese-medium students in general and specifically in their mastery of Chinese, mathematics, and an appreciation of Chinese culture. These findings indicate three points for discussion.

Table 2: Means for the TPB constructs and item statements between parents with children in Chinese- and Malay-medium schools

\begin{tabular}{|c|c|c|c|}
\hline & $\begin{array}{l}\text { Chinese- } \\
\text { medium school } \\
\text { parents }\end{array}$ & $\begin{array}{l}\text { Malay-medium } \\
\text { school parents }\end{array}$ & $t$-values \\
\hline & Mean (SD) & Mean (SD) & \\
\hline Attitude (scale range: $1-10$ ) & $7.1(1.8)$ & $5.7(2.0)$ & $7.402^{*}$ \\
\hline $\begin{array}{l}\text { 1. I believe that studying in Chinese/Malay } \\
\text { school is better than Malay/Chinese } \\
\text { school. }^{c}\end{array}$ & $7.5(2.4)$ & $6.1(2.4)$ & $5.968^{*}$ \\
\hline $\begin{array}{l}\text { 2. I believe that studying in Chinese/Malay } \\
\text { school is better than Malay/Chinese } \\
\text { school in job prospects. }{ }^{c}\end{array}$ & $7.2(2.4)$ & $6.2(2.4)$ & $4.041^{*}$ \\
\hline $\begin{array}{l}\text { 3. I believe that qualifications from } \\
\text { Chinese/Malay school are more valuable } \\
\text { than those from Malay/Chinese school. }\end{array}$ & $7.0(2.3)$ & $6.2(2.5)$ & $3.000^{*}$ \\
\hline $\begin{array}{l}\text { 4. I believe that Chinese/Malay school } \\
\text { students are better than Malay/Chinese } \\
\text { school students in appreciating Chinese }_{\text {culture. }^{\text {c }}}\end{array}$ & $7.6(2.4)$ & $5.2(2.7)$ & $9.201^{*}$ \\
\hline $\begin{array}{l}\text { 5. I believe that Chinese/Malay school } \\
\text { students are better than Malay/Chinese } \\
\text { school students in bahasa Malaysia. }{ }^{c}\end{array}$ & $5.7(2.3)$ & $6.9(2.2)$ & $5.393^{*}$ \\
\hline $\begin{array}{l}\text { 6. I believe that Chinese/Malay school } \\
\text { students are better than Malay/Chinese } \\
\text { school students in English. }{ }^{\mathrm{c}}\end{array}$ & $6.5(2.5)$ & $6.3(2.6)$ & 1.041 \\
\hline
\end{tabular}


Table 2: (continued)

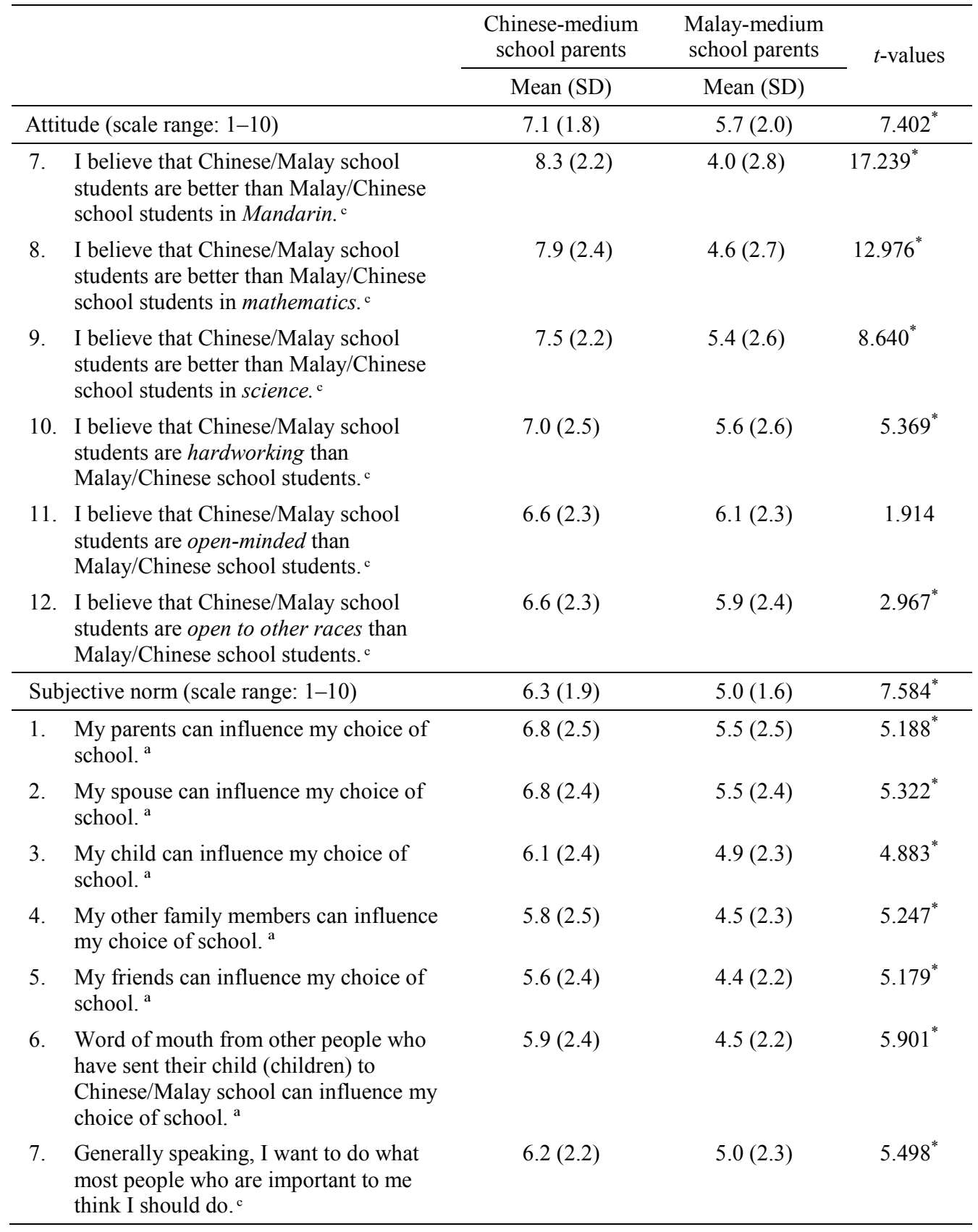


Table 2: (continued)

\begin{tabular}{|c|c|c|c|}
\hline & $\begin{array}{l}\text { Chinese-medium } \\
\text { school parents }\end{array}$ & $\begin{array}{c}\text { Malay-medium } \\
\text { school parents }\end{array}$ & \multirow[t]{2}{*}{$t$-values } \\
\hline & Mean (SD) & Mean (SD) & \\
\hline $\begin{array}{l}\text { Perceived behavioural control } \\
\text { (scale range: } 1-10 \text { ) }\end{array}$ & $7.2(1.7)$ & $7.0(1.8)$ & 1.500 \\
\hline $\begin{array}{l}\text { I. I am certain that if I wanted to I could } \\
\text { enrol my child to the school of my } \\
\text { choice. }{ }^{d}\end{array}$ & $7.7(2.1)$ & $7.4(2.3)$ & 1.458 \\
\hline $\begin{array}{l}\text { 2. For me to decide whether or not to enrol } \\
\text { in Chinese/Malay school was } \\
\text { b }\end{array}$ & $7.1(2.5)$ & $6.7(2.3)$ & 1.775 \\
\hline $\begin{array}{l}\text { 3. Whether I send or not my child } \\
\text { (children) to Chinese/Malay school is } \\
\text { up to me. }{ }^{c}\end{array}$ & $7.4(2.5)$ & $7.4(2.3)$ & -.0720 \\
\hline $\begin{array}{l}\text { 4. I feel I have control in choosing a } \\
\text { Chinese/Malay school in a convenient } \\
\text { location. (none/very much) }\end{array}$ & $7.2(2.3)$ & $6.6(2.5)$ & $2.528^{*}$ \\
\hline $\begin{array}{l}\text { 5. For me to pay the fees is } \\
\text { (difficult/ easy) }\end{array}$ & $6.6(2.4)$ & $6.7(2.5)$ & -.1800 \\
\hline Intention (scale range: $1-10$ ) & $8.0(2.0)$ & $6.2(2.2)$ & $8.426^{*}$ \\
\hline $\begin{array}{l}\text { 1. How strong was the intention to send } \\
\text { your child (children) to Chinese/ Malay } \\
\text { school? }^{\mathrm{e}}\end{array}$ & $8.0(2.1)$ & $6.2(2.3)$ & $8.180^{*}$ \\
\hline $\begin{array}{l}\text { 2. How likely is it that you will send all } \\
\text { your children to Chinese/ Malay school } \\
\text { in the future? }\end{array}$ & $8.0(2.1)$ & $6.3(2.4)$ & $7.664^{*}$ \\
\hline
\end{tabular}

\#Notes: The CP were responding to items on Chinese-medium school whereas the MP were responding to items on Malay-medium school

${ }^{\text {a }}$ Scale, 1 = extremely unlikely to $10=$ extremely likely

b Scale, $1=$ extremely difficult to $10=$ extremely easy

c Scale, $1=$ strongly disagree to $10=$ strongly agree

d Scale, $1=$ definite false to $10=$ definite true

e Scale, $1=$ no intention to $10=$ strong intention

First, both CP and MP expected that Chinese-medium students would have a better command of Chinese because it was the medium of instruction. The time that was allocated for teaching the Chinese subject in both Malay- and Chinese-medium primary schools was the same: 450 minutes per week for Years 1 through 3 and 300 minutes per week for Years 4 through 6 . However, students in Chinese-medium schools also learn other subjects in Chinese. In addition, Chinese is also used in school assemblies and for communication among teachers and students in the school. Notices and other official documents are also in Chinese. By choosing Chinese-medium primary schools, the Chinese parents in this study chose to immerse their children in a Chinese-speaking school environment that inevitably builds a foundation for their children to use Chinese in other domains. As reported by Ting and Mahadhir (2009), some urban Chinese 
parents in Sarawak indicated that one of the primary reasons for choosing Chinese-medium schools was for their children to be able to read the Chinese newspaper.

Second, CP also chose Chinese-medium schools for other academic benefits, and specifically for their children to be able to develop mathematical skills - as shown in the mean values that exceed 6.5 for both CP and MP in Table 2 for the 12 items under Attitudes. Notable achievement in mathematics among Chinese-educated students has been attributed to the Chinese way of learning mathematics, even in American settings. Miller, Kelly and Zhou's (2005) study showed that Chinese-speaking children outperform American children in mathematics. Miller, Kelly and Zhou (2005) explained that the advantage in Chinese mathematics is due to the transparency of the base-ten number system and that the Chinese number naming structure facilitates the learning process (Fuson and Kwon, 1991). Similarly, Ho and Fuson (1998) found that Chinesespeaking children who used the base-ten number system outperformed Englishspeaking children who used Arabic numerals. Miller et al. (2005) asserted that language is one factor that affects early mathematical development. Chinese words that are used for numbers up to 10 have one syllable, while numbers between 11 and 100 have two syllables. Using fewer syllables may facilitate cognitive processes during mathematical computations.

Third, both groups of Chinese parents believed that Chinese-medium schools produce students who have a greater appreciation of Chinese culture than students from Malay-medium schools - which is evident in the mean value of 7.6 for CP and 5.2 for MP for Item 4 of the Attitudes section in Table 2. CP valued the role of Chinese-medium schools as an agent of ethnic socialisation of the Chinese culture. Chinese-medium schools are viewed as a setting that maintains the Chinese language, literature and performing arts, such as Chinese music (Tan, 2005). Through the teaching materials and immersion in a homogeneous Chinese community, students are constantly exposed to Chinese traditional values, beliefs and practices. In comparison, although Malay-medium schools are more ethnically diverse, they show a tendency to move towards a dominant Malay cultural environment.

The results from the present study for attitudes revealed that the $\mathrm{CP}$ believed in the value of Chinese-medium education. However, the value of Malay-medium education for the MP is not clear - except for their children having a better mastery of Malay. Additional research is needed to understand why some Chinese parents diverge from the norm and choose Malay primary schools. Based on our general observations and experiences, we can pinpoint several potential explanations, including a preference for an ethnically diverse student population and avoiding negative traits that are associated with Chinesemedium students (e.g., conforming attitudes, poor mastery of English and Malay), which should be examined in future research. 


\section{Subjective Norms that Govern the Choice of Medium of Instruction}

Table 2 shows that the mean score for CP was $6.3 \pm 1.9$ (range: 1 to 10 ), which indicates marginally positive SN. Parents and spouses influenced CP in their choice for Chinese schools. However, MP made their own school choices $(5.0 \pm$ 1.6), and significantly differed from CP in their likelihood to be influenced by important reference groups (Table 2). The spouse has been identified as the most important reference group in other studies on school choice in monolingual settings (Goh, 2007; Lalwani, Mehta and Tiong, 1999; Sheth, 1974). However, in the present study, CP were also affected by their parents' opinions about the value of Chinese-medium education. The results suggest that the normative choice in the Chinese community is to enrol children in Chinese-medium primary schools. The MP were more similar to parents in monolingual settings because they made school choices that were independent of social pressure (Bagley, 1996; Bussell, 1998; 2000; Schneider, Elacqua and Buckley, 2006; Goldring and Hausman, 1999; Jackson and Bisset, 2005; Kleitz et al., 2000; West et al., 1995).

\section{Perceived Behavioural Control over the Choice of Medium of Instruction}

Both groups of parents were confident that they could enrol their children in the school of their choice (CP: 7.2 \pm 1.7 ; MP: $7.0 \pm 1.8$ ). School location and fees did not limit their choice, but of the two, school location was perceived as a greater constraining factor. $\mathrm{CP}$ could afford the school fees even though they were higher than the fees for Malay-medium schools.

Table 2 shows that there was a significant difference between CP and MP in the control they had in choosing a Chinese- or Malay-medium school that was in a convenient location $(p<0.05)$. CP believed that they had more control over choosing a school in a convenient location than MP because Chinese-medium schools are private schools and regulations for school assignment were not as strict. Some parents used alternative methods, such as providing the utility bills of their relatives who lived in that area or providing evidence of their workplace address, and they were able to register their children earlier. Once they succeeded in enrolling their eldest child in the school, their other children would be given priority for placement in the same school. In contrast, the state education department assigned students to Malay schools based on their residential addresses. Overall, the PBC results showed that both CP and MP were confident that they could enrol their children in a school of their choice.

\section{Intent to Choose Chinese or Malay as a Medium of Instruction}

Table 2 shows that the $\mathrm{CP}$ had a strong intention to choose Chinese-medium schools $(8.0 \pm 2.0)$, while MP's intent to choose Malay-medium schools was only marginally positive $(6.2 \pm 2.2)$. There was also a significant difference 
between CP and MP in their likelihood to choose Chinese or Malay as the medium of instruction for their younger children in the future $(p<0.05)$. In other words, CP were determined to enrol their children in Chinese-medium schools, while MP were not as adamant about their choice.

Table 3 shows that the three independent variables are significantly correlated with each other $(p<0.01)$ and INT for CP, but the relationship is not multicollinear because the correlations between the predictor variables were not above 0.8 or 0.9 (Franke, 2010). CP who were influenced by social norms tended to have more favourable attitudes towards Chinese-medium schools and felt more capable of enrolling their children in these schools, and had strong intentions to choose Chinese-medium primary schools.

Table 3: Correlations among the predictor variables and intention for CP

\begin{tabular}{lllll}
\hline TPB model constructs & INT & AB & SN & PBC \\
\hline INT & 1.00 & & & \\
AB & $0.520^{* *}$ & 1.00 & & \\
SN & $0.397^{* *}$ & $0.554^{* *}$ & 1.00 & \\
PBC & $0.638^{* *}$ & $0.546^{* *}$ & $0.556^{* *}$ & 1.00 \\
\hline
\end{tabular}

${ }^{* *}$ Correlation is significant at the 0.01 level

Table 4 shows that the prediction model was statistically significant for $\mathrm{CP}, \mathrm{F}(5,187)=30.445, p<0.01$, and accounted for $44.0 \%$ of the variance of intention $\left(\mathrm{R}^{2}=0.455\right.$, adjusted $\left.\mathrm{R}^{2}=0.440\right)$. CP's intention was primarily predicted by $\mathrm{PBC}$ (beta $=0.509, p<0.0001$ ) and to a lesser extent by $\mathrm{AB}$ (beta $=0.280, p<0.0001$ ), while $\mathrm{SN}$ was not a significant predictor (beta $=$ $-0.051, p=0.480$ ) (Table 4). CP's age and gender were not significant factors that influenced their intention to choose Chinese-medium primary schools (Table 5). The results indicate that for $\mathrm{CP}$, perceived capability to enrol their children in a Chinese-medium primary school of their choice has more predictive power than attitudes towards Chinese-medium education.

Table 4: Correlations among predictor variables and intention for MP

\begin{tabular}{lllll}
\hline TPB model constructs & INT & AB & SN & PBC \\
\hline INT & 1.00 & & & \\
AB & $0.363^{* *}$ & 1.00 & & \\
SN & -0.108 & $-0.348^{* *}$ & 1.00 & \\
PBC & $0.453^{* *}$ & -0.050 & 0.056 & 1.00 \\
\hline
\end{tabular}

${ }^{* *}$ Correlation is significant at the 0.01 level 
Table 5: Regression analysis of the three independent variables and CP's intention on school choice controlling for age and gender

\begin{tabular}{|c|c|c|c|c|c|c|c|c|c|}
\hline \multicolumn{10}{|c|}{ Model Summary ${ }^{\mathrm{c}}$} \\
\hline \multirow[b]{2}{*}{ Model } & \multirow[b]{2}{*}{$\mathrm{R}$} & \multirow[b]{2}{*}{$\mathrm{R}^{2}$} & \multirow[b]{2}{*}{$\begin{array}{c}\text { Adjusted } \\
\mathrm{R}^{2}\end{array}$} & \multirow{2}{*}{$\begin{array}{l}\text { Std. Error } \\
\text { of the } \\
\text { Estimate }\end{array}$} & \multicolumn{5}{|c|}{ Change Statistics } \\
\hline & & & & & $\begin{array}{c}\mathrm{R}^{2} \\
\text { Change }\end{array}$ & $\begin{array}{c}\mathrm{F} \\
\text { Change }\end{array}$ & df1 & $\mathrm{df} 2$ & $\begin{array}{l}\text { Sig. F } \\
\text { Change }\end{array}$ \\
\hline 1 & $.105^{\mathrm{a}}$ & .011 & .000 & 1.99126 & .011 & 1.033 & 2 & 185 & .358 \\
\hline 2 & $.675^{\mathrm{b}}$ & .455 & .440 & 1.48973 & .444 & 49.511 & 3 & 182 & .000 \\
\hline
\end{tabular}

1. Predictors: (Constant), age, gender

2. Predictors: (Constant), age, gender, AB, SN, PBC

Dependent variable: INT

For MP, the correlation results in Table 6 show that $\mathrm{AB}$ and $\mathrm{PBC}$ were positively correlated with INT, while there was no significant correlation between SN and INT. Their intention to choose Malay-medium schools was related to their attitudes towards Malay-medium schools and the perceived control they had over their choice, which was not influenced by important reference groups in their lives. The MP made their own decisions to choose Malay-medium schools (see the section on Subjective Norms that Govern the Choice of Medium of Instruction). However, the value of the correlation between PBC and INT was lower than that for CP because MP were less certain about whether the state education department would approve their application for enrolling their children in the school of their choice. Malay-medium schools are national schools and the state education department is stricter on student registration conditions than in the national-type Chinese-medium schools.

MP also differed from $\mathrm{CP}$ in that $\mathrm{SN}$ and $\mathrm{AB}$ were negatively and moderately correlated $(\mathrm{r}=-0.348, p<0.01)$ (Table 6$)$. In the social sciences, a correlation coefficient of 0.50 is considered strong (Cohen, 1992). The moderate correlation between $\mathrm{SN}$ and $\mathrm{AB}$ for MP shows that reference groups had a minimal influence on their school choice (see the section on Subjective Norms that Govern the Choice of Medium of Instruction). The negative correlation indicates that a decrease in the influence of subjective norms is accompanied by an increase in MP's favourable attitudes towards Malay-medium schools. This negative correlation can only be understood in context, that is, the norm in the Chinese community is to choose Chinese over Malay-medium schools. MP who chose Malay-medium schools do not succumb to social pressure for choosing Chinese-medium schools and were more likely to positively view Malaymedium schools. 
Table 6: Multiple hierarchical regression analysis of the TPB constructs as it relates to CP's intention for school choice

\begin{tabular}{|c|c|c|c|c|c|c|c|c|}
\hline & \multicolumn{8}{|c|}{ Summary of Multiple Hierarchical Regression Analysis } \\
\hline & \multicolumn{4}{|c|}{ Model 1} & \multicolumn{4}{|c|}{ Model 2} \\
\hline & $\mathrm{B}^{*}$ & $\mathrm{SE}^{*}$ & Beta & Sig. & $\mathrm{B}^{*}$ & $\mathrm{SE}^{*}$ & Beta & Sig. \\
\hline (Constant) & 9.647 & 1.190 & & .000 & 2.659 & 1.062 & & .013 \\
\hline Gender & -.232 & .326 & -.055 & .477 & -.034 & .245 & -.008 & .889 \\
\hline Age & -.033 & .023 & -.109 & .160 & -.023 & .018 & -.075 & .197 \\
\hline $\mathrm{AB}$ & & & & & .310 & .078 & .280 & .000 \\
\hline SN & & & & & -.051 & .073 & -.051 & .480 \\
\hline PBC & & & & & .608 & .084 & .509 & .000 \\
\hline $\mathrm{R}^{2}$ & \multicolumn{4}{|c|}{.011} & \multicolumn{4}{|c|}{.455} \\
\hline Adjusted $\mathrm{R}^{2}$ & \multicolumn{4}{|c|}{.011} & \multicolumn{4}{|c|}{.444} \\
\hline Sig. F & \multicolumn{4}{|c|}{.358} & \multicolumn{4}{|c|}{.000} \\
\hline
\end{tabular}

Note: ${ }^{*}$ Unstandardised coefficients

Table 7 shows that the prediction model was statistically significant for MP, $F(5,183)=18.558, p<0.01$, and accounted for $32.7 \%$ of the variance in intention $\left(\mathrm{R}^{2}=0.343\right.$, adjusted $\left.\mathrm{R}^{2}=0.324\right)$. MP's intention was primarily predicted by PBC (beta $=0.440, p<0.0001)$ and AB (beta $=(0.390, p<0.0001)$ (Table 7). There was no significant relationship for SN (beta $=0.010, p=0.876$ ). For the MP, age and gender were not significantly associated with their intention for school choice (Table 8). Similar to CP, MP's school choice was strongly influenced by perceptions of their capability to enrol their children in a Malaymedium primary school and their attitude towards Malay-medium education. The variance explained for MP's intention was is lower than that for $\mathrm{CP}$, which indicates that there are other factors that need to be examined and were not included in this questionnaire. However, the variance explained for MP (32.4\%) is still within the range that was found in other studies on educational choices: between 30\% and 67\% (Chen and Zimitat, 2006; Cheng and Chu, 2014; Goh, 2007; Ham, 2008; Knabe, 2012; Prugsamatz, 2009; Randall, 1994). 
Table 7: Regression analysis for the three independent variables and MP's intention on school choice while controlling for age and gender

\begin{tabular}{|c|c|c|c|c|c|c|c|c|c|}
\hline \multicolumn{10}{|c|}{ Model Summary $^{c}$} \\
\hline \multirow[b]{2}{*}{ Model } & \multirow[b]{2}{*}{$\mathrm{R}$} & \multirow[b]{2}{*}{$\mathrm{R}^{2}$} & \multirow[b]{2}{*}{ Adjusted $\mathrm{R}^{2}$} & \multirow[b]{2}{*}{$\begin{array}{l}\text { Std. Error of } \\
\text { the Estimate }\end{array}$} & \multicolumn{5}{|c|}{ Change Statistics } \\
\hline & & & & & $\mathrm{R}^{2}$ Change & $\begin{array}{c}\mathrm{F} \\
\text { Change }\end{array}$ & df1 & $\mathrm{df} 2$ & $\begin{array}{l}\text { Sig. F } \\
\text { Change }\end{array}$ \\
\hline 1 & $.126^{\mathrm{a}}$ & .016 & .005 & 2.16236 & .016 & 1.451 & 2 & 181 & .237 \\
\hline 2 & $.585^{\mathrm{b}}$ & .343 & .324 & 1.78199 & .327 & 29.505 & 3 & 178 & .000 \\
\hline
\end{tabular}

Table 8: Multiple hierarchical regression analysis of the TPB constructs as it relates to MP's intention for school choice

\begin{tabular}{|c|c|c|c|c|c|c|c|c|}
\hline & \multicolumn{8}{|c|}{ Summary of Multiple Hierarchical Regression Analysis } \\
\hline & \multicolumn{4}{|c|}{ Model 1} & \multicolumn{4}{|c|}{ Model 2} \\
\hline & $\mathrm{B}^{*}$ & $\mathrm{SE}^{*}$ & Beta & Sig. & $\mathrm{B}^{*}$ & $\mathrm{SE}^{*}$ & Beta & Sig. \\
\hline (Constant) & 4.503 & 1.255 & & & -1.866 & 1.405 & & .186 \\
\hline Gender & .573 & .347 & .127 & .100 & .559 & .287 & .124 & .053 \\
\hline Age & .020 & .023 & .067 & .386 & .023 & .019 & .077 & .235 \\
\hline $\mathrm{AB}$ & & & & & .433 & .073 & .390 & .000 \\
\hline $\mathrm{SN}$ & & & & & .013 & .084 & .010 & .876 \\
\hline PBC & & & & & .537 & .075 & .440 & .000 \\
\hline $\mathrm{R}^{2}$ & \multicolumn{4}{|c|}{.016} & \multicolumn{4}{|c|}{.343} \\
\hline Adjusted $\mathrm{R}^{2}$ & \multicolumn{4}{|c|}{0.16} & \multicolumn{4}{|c|}{.327} \\
\hline Sig. F & \multicolumn{4}{|c|}{.237} & \multicolumn{4}{|c|}{.000} \\
\hline
\end{tabular}

Note: ${ }^{*}$ Unstandardised coefficients

In this study, the strong influence of PBC on intention indicates that the choice of a Chinese- or Malay-medium primary school puts school choice in Malaysia in the category of behaviours that are not under volitional control. In this category, studies that use TPB have shown that PBC is a primary factor that influences intentions, such as applications for enrolling in business ethics courses (Cheng and Chu, 2014; Randall, 1994), but when students have adequate resources, including perceived capability to perform well, PBC contributed little in predicting intentions (Chen and Zimitat, 2006; Prugsamatz, 2009; Pineda, 2009). In the present study, the Chinese parents could afford to pay for the school fees but they were unsure about whether they could secure a place for their children in the preferred school due to government-imposed conditions on student enrolment based on residential zoning. 
The regression analysis controlled for the influence of demographic variables, age and gender, as these could influence parental school choice. The results that are shown in Tables 5-8 (Model 2) showed that age and gender did not significantly influence CP and MP's intentions for choosing Chinese- or Malay-medium primary schools, which provide empirical support for Ajzen and Fishbein's (1975) contention that little information can be gained from including demographic variables in the TPB.

\section{CONCLUSION}

The factors that influence Chinese parents' choice of primary school in Sarawak, Malaysia, was studied within the context of TPB, which groups motivational factors for intended behaviours under $\mathrm{PBC}, \mathrm{AB}$ and $\mathrm{SN}$. This study identified $\mathrm{PBC}$ as the strongest predictor of Chinese parents' school choice. Chinese parents can afford to pay fees but experience constraints in enrolling their children in the Chinese- or Malay-medium school of their choice due to government regulations that assign schools based on residential addresses. Although they have alternative methods for enrolling their children in their preferred school, they do not have volitional control over the outcome of their application. The final decision rests with the Chinese-medium school or the state education department, for Malaymedium schools. The largest challenge is to enrol the eldest child in the preferred school, after which there are rarely problems because siblings are given priority for placement in the same school. Other studies have shown that PBC is a primary factor that influences education-related intentions when the behaviour is not under volitional control (Cheng and Chu, 2014; Randall, 1994).

$\mathrm{AB}$ moderately influences intention, while $\mathrm{SN}$ add little explanatory power in predicting intentions to enrol children in Chinese- or Malay-medium primary schools. Although the parents who choose Chinese schools are influenced by their parents and spouses, SN have little explanatory power in predicting school choice. Most other studies on education-related intentions that used TPB identified that attitudes towards behaviour were the most important factor (Chen and Zimitat, 2006; Goh, 2007; Ham, 2008; Prugsamatz, 2009; Randall, 1994). In the present study, AB, SN and PBC collectively accounted for $44.0 \%$ and $32.4 \%$ of the variance in Chinese parents' intentions for choosing Chinese- and Malay-medium schools, respectively. To account for the influence of participants' demographic characteristics on the results, the relationship between age and gender and intent was analysed, with no significant relationships for either group of Chinese parents. These findings concur with Knabe (2012) and Ajzen and Fishbein (1975) in that demographic variables do not influence the intention to perform a particular behaviour compared to $\mathrm{AB}, \mathrm{SN}$ and $\mathrm{PBC}$.

$\mathrm{PBC}$ is a matter of financial capability and navigating the technicalities of enrolment procedures, while attitudes toward school are personal motivations 
that influence school choice. Our findings indicate that choosing a Chinesemedium school is more than a choice of language of instruction. A Chinesemedium primary school uses Chinese as the medium of instruction and the official language for meetings and notices as well as in informal interactions in the school. The teaching materials are also based on Chinese culture; therefore, the transmitted values are also primarily Chinese. The cultural differences are reflected in the teaching approaches, which may explain why Chinese-medium school students are known for their mathematics skills and character development (e.g., diligence). Lee (2012) believes that Chinese parents regard mother-tongue education as integral to the survival of "Chineseness" in Malaysia and essential for preserving the language, culture and identity. These may result in ethnocentrism, and the Chinese-medium school students may develop Chinesecentric worldviews in social and ethnic relations and other aspects of life. Lee (2012) states that more Chinese parents are choosing Chinese-medium schools in protest of the "increasing Islamization of the national schools" (p. 175). This aspect was not explored in the present study. Because religion is a sensitive issue in Malaysia, future research should examine its influence on school choice rather than solely focusing on the Chinese community's motivations for choosing Chinese-medium schools. This is because many studies that have used enrolment statistics as well as data on Chinese education and culture have concluded that the value that is attached to Chinese schools are as an agent of Chinese cultural transmission and maintenance. Nevertheless, the conclusions of the present study are limited to urban Chinese parents in Malaysia. These findings are culturespecific because languages have their respective roles and statuses in different communities.

It may be more insightful to explore the alternative perspective, that is, why a large proportion of Chinese parents did not choose Malay-medium primary schools. This is a matter of national concern because Malay-medium schools are the agents of national integration, and when a large proportion of Chinese children are not in the national schools, then integration-oriented ideals cannot be imparted to these children. In the years since the independence of Malaysia, when English was the medium of instruction, researchers have noted that parents who enrolled their children in English schools were more nationalistic and less communal than those who chose Chinese-medium schools (Bock, 1970). Exploring why Malay-medium primary school is not the preferred choice for Chinese parents will complement existing research on the preference for Chinesemedium schools, and provide a holistic perspective on the factors that influence school choice for the Chinese community in Malaysia.

Researchers on school choice in Malaysia should also investigate why certain quarters of the Chinese community choose Malay-medium primary schools. The present study was not able to identify the motivations of Chinese parents who chose Malay-medium primary schools compared to the parents who choose Chinese-medium primary schools, which was demonstrated in the lower 
percentage of variance explained. The Chinese parents who chose Malay-medium schools believed that their children would be proficient in Malay but acknowledged that Chinese students were better in Chinese and mathematics, and had a stronger appreciation for Chinese culture. However, because these parents did not choose Chinese-medium schools, these factors are not important. Additional research is needed to understand why Chinese parents diverge from the norm in the Chinese community and choose Malay-medium primary schools. The present study used questionnaires; however, we suggest that interviews would unearth information that may be specific to the local context or the individuals. Furthermore, interviews are more appropriate for drawing out ethnicity-related reasons, which was discovered by Denessen, Driessena and Sleegers (2005) and Weiher and Tedin (2002). Because school choice has a longterm impact on children's propensity for using specific languages later in life and broader impacts on integration in nation building, more research is needed to investigate factors that influence school choice in rural localities and for other ethnic groups.

\section{APPENDIX}

Appendix 1: Kaiser-Meyer-Olkin Measure of Sampling Adequacy and Bartlett's Test of Sphericity

\begin{tabular}{lccc}
\hline & & $\begin{array}{c}\text { Chinese-medium } \\
\text { school parents }\end{array}$ & $\begin{array}{c}\text { Malay-medium school } \\
\text { parents }\end{array}$ \\
\hline $\begin{array}{l}\text { Kaiser-Meyer-Olkin Measure } \\
\text { of Sampling Adequacy }\end{array}$ & & .817 & .854 \\
\hline $\begin{array}{l}\text { Bartlett's Test of } \\
\text { Sphericity }\end{array}$ & Approx. Chi-Square & 5365.968 & 3675.205 \\
& df & 780 & 378 \\
& Sig. & .000 & .000 \\
\hline
\end{tabular}

\section{REFERENCES}

Ajzen, I. 1991. The theory of planned behavior. Organizational Behavior and Human Decision Processes 50: 179-211. http://www .valuebasedmanagement.net/methods_ajzen_theory_planned_behaviour. html. https://doi.org/10.1016/0749-5978(91)90020-T.

Ajzen, I. 2002. Perceived behavioral control, self-efficacy, locus of control, and the theory of planned behavior. Journal of Applied Social Psychology 32: 665-683. https://doi.org/10.1111/j.1559-1816.2002.tb00236.x.

Ajzen, I. and M. Fishbein. 1975. Belief, attitude, intention and behavior: An introduction to theory and research reading. MA: Addison-Wesley. 
Armitage, C. J., M. Conner and P. Norman. 1999. Differential effects of mood on information processing: Evidence from the theories of reasoned action and planned behavior. European Journal of Social Psychology 29: 419-433. $\quad$ http://www.ssc.wisc.edu/ jpiliavi/965/mood.pdf. https://doi.org/10.1002/(SICI)1099-0992(199906)29:4<419::AIDEJSP933>3.3.CO;2-C.

Babaci-Wilhite, Z. 2010. Why is the choice of the language of instruction in which students learn best seldom made in Tanzania. In Educational challenges in multilingual societies: LOITASA phase two research, eds. Z. Desai, M. A. Qorro and B. Brock-Utne, 281-305. Oxford, UK: African Books Collective.

Bagley, C. 1996. Black and white unite or flight? The racialised dimension of schooling and parental choice. British Educational Research Journal 22: 569-580. https://doi.org/10.1080/0141192960220504.

Bamberg, S., I. Ajzen and P. Schmidt. 2003. Choice of travel mode in the theory of planned behavior: The roles of past behavior, habit, and reasoned action. http://www.darkcoding.net/research/travelmode.pdf.

Bock, J. C. 1970. Education and nation-building in Malaysia: A study of institutional effect in thirty-four secondary schools. PhD diss., Stanford University, Carlifornia.

Bussell, H. 2000. Choosing a school: The impact of social class on the primary school decision-making process. International Journal of Nonprofit and Voluntary Sector Marketing 5(4): 373-387. https://doi.org/10.1002/nvsm. 127.

1998. Parental choice of primary school: An application of Qmethodology. The Service Industries Journal 18(3): 135-147. https://doi.org/10. 1080/02642069800000036.

Chen, C. H. and C. Zimitat. 2006. Understanding Taiwanese students' decisionmaking factors regarding Australian international higher education. International Journal of Educational Management 20(2): 91-100. https://doi.org/10. 1108/09513540610646082.

Cheng, P. Y. and M. C. Chu. 2014. Behavioral factors affecting students' intentions to enrol in business ethics courses: A comparison of the Theory of Planned Behavior and Social Cognitive Theory using selfidentity as a moderator. Journal of Business Ethics 124: 35-46. https://doi.org/10.1007/s10551-013-1858-0.

Chua, C. S. K. 2009. A new concept of "bilingualism" for the IT age. Current Issues in Language Planning 10: 442-455. https://doi.org/10.1080/ 14664200903554982. 2004. Singapore's literacy policy and its conflicting ideologies. Current Issues in Language Planning 5: 64-76. https://doi.org/10.1080/ 14664200408669080 . 
Chuchinprakarn, S. 2005. Application of the theory of reasoned action to on-line shopping.

http://www.bu.ac.th/knowledgecenter/epaper/jan june2005/supanat .pdf.

Cohen, J. 1992. A power primer. Psychological Bulletin 112: 155-159. https://doi.org/10.1037/0033-2909.112.1.155.

Denessen, E., G. Driessena and P. Sleegers. 2005. Segregation by choice? A study of group-specific reasons for school choice. Journal of Education Policy 20: 347-368. https://doi.org/10.1080/02680930500108981.

Department of Statistics Malaysia. 2016. Quick population info. https://www.statistics.gov.my/ . 2015. Population quick info. http://pqi.stats.gov.my/result.php?token= 26ed65eedeecaeecbc4f5488f0682fb2.

Evans, R. and A. Cleghorn. 2014. Parental perceptions: A case study of school choice amidst language waves. South African Journal of Education 34(22): 1-19. https://doi.org/10.15700/201412071203.

Fleming, M. L., J. C. Barner, C. M. Brown, M. D. Shepherd, S. Strassels and S. Novak. 2014. Using the theory of planned behavior to examine pharmacists' intention to utilize a prescription drug monitoring program database. Research in Social and Administrative Pharmacy 10: 285-296. https://doi.org/10.1016/j.sapharm.2013 .05.009.

Franke, G. R. 2010. Multicollinearity. Wiley international encyclopedia of marketing. New Jersey: Wiley-Blackwell. https://doi.org/10. 1002/9781444316568. wiem02066.

Fuson, K. C. and Y. Kwon. 1991. Chinese-based regular and European irregular systems of number words: The disadvantages for English-speaking children. In Language and mathematics education, eds. K. Durkin and B. Shire, 211-226. Milton Keynes: Open University Press.

Gill, S. K. 2005. Language policy in Malaysia: Reversing direction. Language Policy 4: 241-260. https://doi.org/10.1007/s10993-005-7859-9.

Goh, E. 2007. Primary school choice selection: Examining parental school choice decision behavior using the theory of reasoned action and the theory of planned behavior. Master's thesis, University of Wollongong, Australia. https://doi.org/10.1002/9781444316568.wiem02066.

Goldring, E. B. and C. S. Hausman. 1999. Reasons for parental choice of urban schools. Journal of Education Policy 14: 469-490. https://doi.org/10.1080/026809399286161.

Hair, J. F., R. E. Anderson, R. L. Tatham and W. C. Black. 1992. Multivariate data analysis: With readings. 3rd ed. New York: Macmillan Publishing Company.

Ham, S. R. 2008. An analysis of factors shaping students' decision to study or not to study Languages Other than English (LOTE) in Queensland State secondary schools. PhD diss., Griffith University, Australia. 
Ho, C. S. H. and K. C. Fuson. 1998. Children's knowledge of teen quantities as tens and ones: Comparisons of Chinese, British, and American kindergartners. Journal of Educational Psychology 90: 536-544. http://dx.doi.org/10.1037/0022-0663.90.3.536.

Huajiao Daobao. 2011. Chinese Eucation Bulletin 81(2).

Jackson, C. and M. Bisset. 2005. Gender and school choice: Factors influencing parents when choosing single-sex or co-educational independent schools for their children. Cambridge Journal of Education 35: 195-211. http://dx.doi.org/10 .1080/03057640500146856.

Kleitz, B., G. R. Weiher, K. Tedin and R. Matland. 2000. Choice, charter schools and household preferences. Social Science Quarterly 81: 846-854. http://www.jstor.org/stable/42864008.

Knabe, A. P. 2012. Applying Ajzen's theory of planned behavior to a study of online course adoption in public relations education. $\mathrm{PhD}$ diss., Marquette University, Milwaukee. http://epublications.marquette. edu/cgi/viewcontent.cgi?article $=1186 \&$ context $=$ dissertations_mu.

$\mathrm{Ku}, \mathrm{H}$. B. 2003. Moral politics in a South Chinese village: Responsibility, reciprocity and resistance. Lanham: Rowman \& Littlefield.

Lalwani, A., S. Mehta and T. C. Tiong. 1999. Family roles in the selection of schools in multiracial Singapore: An examination of demographic differences. Journal of Professional Services Marketing 19(2): 73-92. https://doi.org/10.1080/ 15332969.1999.9985368.

Lee, H. G. 2012. Education of the Chinese in Malaysia. In Malaysian Chinese: Recent developments and prospects, eds. H. G. Lee and L. Suryadinata, 166-192. Singapore: Institute of Southeast Asian Studies.

Man, K. C. 1998. Predicting unethical behavior: A comparison of the theory of reasoned action and the theory of planned behavior. Journal of Business Ethics 17: 1825-1834. https://doi.org/10.1023/A:1005721401993.

Miller, K. F., M. K. Kelly and X. Zhou. 2005. Learning mathematics in China and the United States: Cross-cultural insights into the nature and course of mathematical development. In Handbook of mathematical cognition, ed. J. I. D. Campbell, 163-178. New York: Psychology Press. http://www.rcgd.isr.umich.edu/life/Readings2007/Miller\%20Ed\%20Read ing\%201.pdf.

Ministry of Education. 2012. Preliminary report: Malaysia education blueprint 2013-2025. Kuala Lumpur: Ministry of Education.

Norman, P., M. Conner and R. Bell. 1999. The theory of planned behaviour and smoking cessation. Health Psychology 18: 89-94.

Pineda, R. C. 2009. What motivates U.S. business students to take international business courses? Journal of Education for Business 84(3): 177-182. https://doi.org/10.3200/JOEB.84.3.177-182. 
Prugsamatz, S. 2009. International students' higher education choice: Using the theory of planned behaviour to identify key choice attributes by segment. $\mathrm{PhD}$ diss., University of Queensland, Australia.

Raman, S. R. and Y. S. Tan. 2010. Ethnic segregation in Malaysia's education system: enrolment choices, preferential policies and desegregation. Paedagogica Historica 46: 117-131. http://dx.doi.org/10.1080 /00309230903528496.

Randall, D. M. 1994. Why students take elective business ethics courses: Applying the theory of planned behavior. Journal of Business Ethics 13: 369-378. https://doi.org/10.1007/BF00871764.

Ridge, B. 2003. Malaysia's English language policies for the 21st century Where to now. Asian Profile 31: 29-36.

Santhiram, R. R. and Y. S. Tan. 2015. The development of Chinese education in Malaysia: Problems and challenges. In ISEAS Yusof Ishak Institute Working Papers, No. 2, ed. H. G. Lee, 1-28. https://www.iseas.edu.sg /images/ pdf/WP2015-02.pdf.

Schneider, M., G. Elacqua and J. Buckley. 2006. School choice in Chile: Is it class or the classroom? Journal of Policy Analysis and Management 25: 577-601. https://doi.org/10.1002/pam.20192.

Sheth, J. N. 1974. A theory of family buying decisions. In Models of buyer behaviour: Conceptual, quantitative, and empirical, ed. J. N. Sheth, 1733. New York: Harper and Row. http://www.jagsheth.com/wpcontent/uploads/2014/02/ a_theory_of_family_buying_decisions.pdf.

Siragusa, L. and K. C. Dixon. 2009. Theory of planned behaviour: Higher education students' attitudes towards ICT-based learning interactions. http://www.ascilite.org.au/conferences/auckland09/procs/siragusa.pdf.

Smith, K. J. 2003. Minority language education in Malaysia: Four ethnic communities' experiences. International Journal of Bilingual Education and Bilingualism 6: 52-65. https://doi.org/10.1080/136700 50308667772.

Suryadinata, L. 1997. Ethnic Chinese as Southeast Asians. Singapore: Institute of Southeast Asian Studies. https://doi.org/10.1007/978-1-137-07635-9.

Tan, P. K. W. 2005. The medium-of-instruction debate in Malaysia English as a Malaysian language? Language Problems \& Language Planning 29: 4766. http://www.teo-education.com/teophotos/albums/userpics/debate.pdf. https://doi. org/10.1075/lplp.29.1.04tan.

Tan, Y. S., K. Ngah and S. M. Darit. 2013. Parental choice of schooling, learning processes and inter-ethnic friendship patterns: The case of Malay students in Chinese primary schools in Malaysia. International Journal of Educational Development 33: 325-336. https://doi.org/10. 1016/j.ijedudev.2012.09.002. 
Tan, M. J. 1997. The ethnic Chinese in Indonesia: Issues of identity. In Ethnic Chinese as Southeast Asians, ed. L. Suryadinata, 33-65. Singapore: Institute of Southeast Asian Studies. https://doi.org/10.1007/978-1-13707635-9 4.

Teh, W. S. 2014. Blaming vernacular schools for racial disharmony: Why does this belief persist? http://www.malaysiandigest.com/opinion/523474blaming-vernacular-schools-for-racial-disharmony-why-does-this-beliefpersist.html.

The Borneo Post. 10 April 2013. RM15.5m for Chinese primary schools. http://www.pemandu.gov.my/gtp/Media_Coverage-@-RM15@5m_for_ Chinese_primary_schools.aspx \#sthash.uPItIVGk.dpuf

The Star. 10 January 2015. Enrolment in Chinese primary schools sees a drop. http://www.thestar.com.my/news/nation/2015/01/10/enrolment-inchinese-primary-schools-sees-a-drop/

Ting, H. M. H. 2013. Language, identity and mobility: Perspective of Malaysian Chinese youth. Malaysian Journal of Chinese Studies 2: 83-102. . 2005. Education and identity: A study on Chinese secondary education in Malaysia (1945-2000). Xiamen: Xiamen University Press.

Ting, S. H. 2012. Variable impact of Malaysia's national language planning on non-Malay speakers in Sarawak. Revista Brasileira de Linguistica Aplicada 12(2): 381-403. https://doi.org/10.1590/S1984-639820120002 00008 .

2010. Impact of language planning on language choice in friendship and transaction domains in Sarawak, Malaysia. Current Issues in Language Planning 11(4): 397-412. https://doi.org/10.1080/14664208.2010. 545573.

Ting, S. H. and M. Mahadhir. 2009. Towards homogeneity in home languages. Australian Review of Applied Linguistics (ARAL) 32(2): 11.1-11.22.

Ting, S. H. and T. Y. Ling. 2012. Language use and sustainability status of indigenous languages in Sarawak. Journal of Multilingual and Multicultural Development 33(6): 1-17. https://doi.org/10.1080/01434 632.2012.706301.

Tsui, A. B. M., M. S. K. Shum, C. K. Wong, S. K. Tse and W. W. Ki. 1999. Which agenda? Medium of instruction policy in post-1997 Hong Kong. Language Culture and Curriculum 12(3): 196-214. http://hub.hku.hk/bitstream/10722/42374/1/50495.pdf?accept=1. https:// doi.org/10.1080/07908319908666578.

Vallerand, R. J., P. Deshaies, J. Cuerrier, L. G. Pelletier and C. Mongeau. 1992. Ajzen and Fishbein's theory of reasoned action as applied to moral behaviour: A confirmatory analysis. Journal of Personality and Social Psychology 62: 98-109. https://doi.org/10.1037/0022-3514.62.1.98. 
Vidovich, L. and M. S. Yap. 2008. Global-local dynamics in expanding school choice in Singapore. In The globalisation of school choice, eds. M. Forsey, S. Davies and G. Walford, 209-230. Oxford: Symposium Books.

Vincent, P. C., L. A. Peplau and C. T. Hill. 1998. A longitudinal application of the theory of reasoned action to women's career behavior. Journal of Applied Social Psychology 28: 761-778. https://doi.org/10.1111/j.15591816.1998.tb01730.x.

Weiher, G. R. and K. L. Tedin. 2002. Does choice lead to racially distinctive schools? Charter schools and household preferences. Journal of Policy Analysis and Management 21: 79-92. https://doi.org/10.1002/pam.1041.

West, A., M. David, J. Hailes and J. Ribbens. 1995. Parents and the process of choosing secondary schools: Implications for schools. Educational Management and Administration 23(1): 28-38.

Yi, M. Y. and F. D. Davis. 2003. Developing validating an observational learning model of computer software training and skill acquisition. Information Systems Research 14: 146-169. https://doi.org/10.1287/isre.14.2. 146.16016.

Zellweger, T., P. Sieger and F. Halter. 2010. Should I stay or should I go? Career choice intentions of students with family business background. Journal of Business Venturing 26(5): 521-536. https://doi.org/10.1016/j.jbusvent 2010.04.001. 